Stano, G. T., C. J. Schultz, L. D. Carey, D. R. MacGorman, and K. M. Calhoun, 2014: Total lightning observations and tools for the 20 May 2013 Moore, Oklahoma, tornadic supercell. J. Operational Meteor., 2 (7), 71-88, doi: http://dx.doi.org/ 10.15191/nwajom.2014.0207.

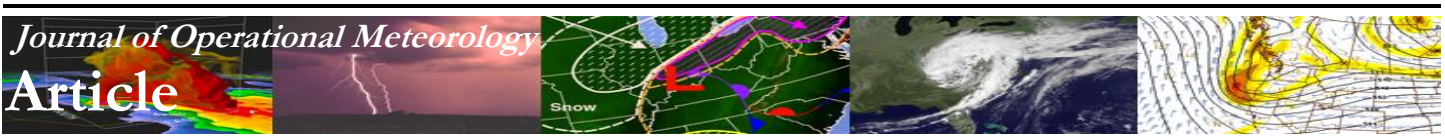

\title{
Total Lightning Observations and Tools for the 20 May 2013 Moore, Oklahoma, Tornadic Supercell
}

\author{
GEOFFREY T. STANO \\ NASA Short-term Prediction Research and Transition Center/ENSCO, Inc., Huntsville, Alabama \\ CHRISTOPHER J. SCHULTZ \\ NASA Marshall Space Flight Center/University of Alabama in Huntsville, Huntsville, Alabama \\ LAWRENCE D. CAREY \\ Department of Atmospheric Science, University of Alabama in Huntsville, Huntsville, Alabama \\ DONALD R. MACGORMAN \\ NOAA/National Severe Storms Laboratory, Norman, Oklahoma \\ KRISTIN M. CALHOUN \\ Cooperative Institute for Mesoscale Convective Studies, University of Oklahoma, and NOAA/NSSL, Norman, Oklahoma
}

(Manuscript received 24 October 2013; review completed 11 February 2014)

\begin{abstract}
On 20 May 2013, a supercell thunderstorm developed west-southwest of Newcastle, Oklahoma, and eventually produced an EF-5 tornado that struck Moore, Oklahoma. This article describes how total lightning observations associated with this rotating storm could benefit warning operations. This effort focuses on (i) the Geostationary Operational Environmental Satellite- $R$ pseudo-geostationary lightning mapper product, (ii) the National Aeronautics and Space Administration's Short-term Prediction Research and Transition Center/Meteorological Development Laboratory's total lightning tracking tool, and (iii) a real-time lightning jump algorithm currently under development. Use of these three tools revealed a distinct increase or "jump" in the storm's lightning flash rates prior to reported severe weather. Lightning jumps occurred 19 min prior to severe hail and coincided with the storm's initial growth, while the second lightning jump occurred 26 min prior to tornado touchdown. This second jump accompanied an increase in rotational depth and strength. These rapid increases in total lightning activity can provide improved situational awareness to forecasters, as lightning jumps relate to the rapid strengthening of a storm's updraft and serve as a precursor to the stretching of the storm vortex prior to severe weather events. Although lightning jumps alone do not always indicate imminent severe weather, they (i) have the potential to help reduce false alarms and (ii) can guide forecasters to issue warnings earlier than they would have with radar data alone.
\end{abstract}

\section{Introduction}

A robust correlation between a rapid increase in total lightning (i.e., lightning jumps) and severe weather has been well documented (e.g., Goodman et al. 1988, 2005; MacGorman et al. 1989; Williams et al. 1999; Schultz et al. 2009, 2011; Gatlin and Goodman 2010). Current lightning jump research focuses on the development of an algorithm to automatically detect lightning jumps to aid in the severe weather warning process (e.g., Schultz et al. 2009, 2011; Gatlin and
Goodman 2010; Hodanish et al. 2013). Total lightning data (i.e., both intracloud and cloud-to-ground observations) provide rapid temporal updates on changes in a thunderstorm's updraft characteristics at sub-radar volume-scan times. Upon launch of the Geostationary Operational Environmental Satellite-R (GOES-R; Goodman et al. 2012), total lightning data will be available continuously from the Geostationary Lightning Mapper (GLM; Christian et al. 1989, 1992; Christian 2006; 
Goodman et al. 2013) with a 20-s latency for data processing.

Although lightning jumps can indicate increasing potential for severe weather, Metzger and Nuss (2013) and Schultz et al. (2013) found that lightning jumps alone are insufficient to discriminate one type of severe weather from another. Thus, in order to use total lightning data and the lightning jump concept more effectively in the severe weather warning decision-making process, they must be combined with other observations, such as near-storm environmental data, radar, and satellite imagery (Schmit et al. 2005). Goodman et al. (1988, 2005) analyzed two severe weather cases where strong vertical growth was indicated by radar and that were accompanied by a rapid increase in total lightning flash rate prior to the onset of damaging microbursts in northern Alabama. Another case by Gatlin and Goodman (2010) described how the low-level radial shear, which was associated with the development of an F-1 tornado, increased just after a lightning jump. This jump occurred about $20 \mathrm{~min}$ prior to the tornado's development. Furthermore, White et al. (2012) noted that increasing total lightning source densities were driven by strong updrafts reaching the mixed-phase region of a storm. The source densities increased as the maximum radar reflectivity increased aloft at approximately $-20^{\circ} \mathrm{C}$ (i.e., the mixed-phase region). In a separate study, Schultz et al. (2013) found that the mean vertical profile of reflectivity increased in 329 storms during the $10 \mathrm{~min}$ prior to a lightning jump and decreased during the 10 min after the jump. This also was noted in a different case by Williams et al. (1999). Recently, Metzger and Nuss (2013) demonstrated that there was rapid vertical growth of the 55-dBZ contour as a lightning jump was occurring in 64 of 69 observed cases.

The relationship between total lightning and the mixed-phase updraft is what indirectly connects the lightning jump to high-impact weather. The lightning jumps in two storms observed by the Kennedy Space Center's Lightning Detection and Ranging (Lennon 1975; Lennon and Maier 1991) network coincided with explosive vertical development and were precursors to severe weather (Williams et al. 1999). For these severe storms, the peak flash rate was most closely related to the vertical extent of the radar reflectivity in the mixed-phase region at low levels. As Williams et al. (1999) described, this was consistent with the hypothesis that supercooled water was a key ingredient for electrification, as suggested by the laboratory studies of graupel-ice charge exchange by Takahashi (1978) and Jayaratne et al. (1983). This indirect connection between total lightning and severe weather assumes a primary (i.e., causative) physical connection between the mixed-phase updraft and the severe weather (e.g., riming growth of large hail, precipitation loading, and melting in downdrafts for straight-line wind events). As such, a quasi-steady and "rotating updraft" is not required for the lightning jump to be useful in a general severe weather scenario. Furthermore, several studies have found that total flash rates were correlated with a storm's updraft volume of mass flux (e.g., Lang and Rutledge 2002; Kuhlman et al. 2006; Deierling and Petersen 2008; Calhoun et al. 2013a).

The updraft itself plays a role in tornadogenesis through a series of events. Davies-Jones (1984) stated that the rotation of a storm's updraft originates with the tilting of streamwise vorticity, and this rotation leads to the development of the storm's mesocyclone. This development is important for severe weather forecasting as nearly $90 \%$ of storms with mesocyclones produce severe weather (Stumpf et al. 1998), in which $26 \%$ of detected mesocyclones produce tornadoes (Trapp et al. 2005). The tilting of streamwise vorticity, coupled with low-level convergence, leads to vertical stretching of vortex tubes, thereby contributing to increases in cyclonic vertical vorticity (Lemon and Doswell 1979; Davies-Jones 1984; Roberts and Wilson 1995).

The direct physical connection between the midlevel mesocyclone and tornadogenesis-and therefore the indirect connection between the lightning jump and tornadogenesis - is complex. As previously mentioned by Trapp et al. (2005), there is only a weak association between mesocyclone occurrence and tornadogenesis. Research suggests the importance of the rear flank downdraft (RFD; Lemon and Doswell 1979) for vortex stretching at the lowest levels. The RFD transports angular momentum from within the mesocyclone to the ground (e.g., Adlerman et al. 1999; Markowski et al. 2003; Davies-Jones 2008). As this low-level angular-momentum-rich air reaches the surface, it contributes to the previously mentioned surface convergence and vertical stretching upon being ingested into the storm's main updraft (Fujita 1975; Markowski et al. 2003; Davies-Jones 2008). Numerous studies have concluded that the likelihood of a tornado, its intensity, and longevity increase as the deficit between the equivalent potential temperature within the RFD and the updraft is reduced (e.g., 
Markowski 2002; Grzych et al. 2007; Markowski and Richardson 2009; Lee et al. 2012).

The discussion above can be combined to create a conceptual and/or operational model for using total lightning in a supercell environment (e.g., Fawbush and Miller 1954; Bluestein 1993, pp. 475-492; Thompson et al. 2003, 2012)—such as on 20 May 2013. As a storm initiates in an environment with favorable convective available potential energy (CAPE) and shear, a rapid increase in total lightning suggests that the storm updraft is intensifying. This inference comes from total lightning being driven by rapid increases in the vertical velocity of the updraft in the mixed-phase region. As vertical velocities increase, the mesocyclone develops with streamwise vertical vorticity accelerating in the midlevels. At this point, tornadogenesis will depend on the favorability of the RFD, as discussed above. The forecaster will infer this rapidly increasing vertical motion in the mixed-phase region with total lightning before they will see it with radar. Warnings presumably can be issued earlier based on the total lightning data. Additional radar and near-storm environment data will be needed to determine if the warning will be a severe thunderstorm or tornado warning.

Several studies have evaluated the impact of using this conceptual model of the relationship between lightning jumps and storm severity in an operational or quasi-operational setting for both supercell and nonsupercell environments. For example, Darden et al. (2010) reviewed how lightning jumps were related to the rapid development of a mesocyclone and an EF-4 tornado during the 6 February 2008 severe weather outbreak in northern Alabama. White et al. (2012) described how the lightning jump concept provided guidance for issuing the initial tornado warning during the onset of the 2 March 2012 tornado outbreak in the Huntsville, Alabama, county warning area. Furthermore, Goodman et al. (2013) presented a case in which the lightning jump played a vital role in aiding the operational forecaster in deciding to issue a tornado warning during the development of a quasi-linear convective system (QLCS) tornado in northern Alabama. These examples show how lightning jumps can aid warning operations both when the environment is favorable for supercell storms and when the situation is less clear or harder to forecast (e.g., the QLCS). Use of lightning jumps can alert a forecaster to a rapidly developing storm and can provide increased confidence in warning decisions. Assessments of the use of total lightning observations in operations have demon- strated improvements in warning lead times, situational awareness, and lightning safety (Hodanish et al. 1998; Bridenstine et al. 2005; Goodman et al. 2005; Demetriades et al. 2008; Nadler et al. 2009; Stano et al. 2010a; Stano 2012).

The goal of this paper is to demonstrate how the use of total lightning data could contribute to warning decision support during severe weather operations in the future. None of the lightning data tools described herein were available to operational forecasters in realtime during the storm that produced the 20 May 2013 tornado in Moore, Oklahoma. This paper is not intended as an exhaustive analysis of that storm's genesis and life cycle. Instead, this paper will demonstrate collaborative capabilities under development, as well as how these future capabilities could fit within operational warning practices. This article focuses on how these tools can support and enhance the operational warning decision-making process. These data also can aid situational awareness, particularly by providing the specific locations at which thunderstorms are beginning to develop. Our hope is that examples like the ones presented here can help forecasters add techniques for using new observational capabilities during severe weather warning operations.

The remainder of this paper will focus on the evaluation of total lightning observations and visualization tools with respect to the Moore, Oklahoma, tornadic supercell. Section 2 provides background on the total lightning data, products, and tools used in this post analysis, and quickly highlights total lightning available in operations now. Section 3 provides analyses from the total lightning perspective of the Moore supercell from the supercell's genesis around 1900 UTC to tornadogenesis at 1956 UTC 20 May 2013. Section 4 provides a brief discussion of the event and how the visualization tools could fit into the warning decision support environment.

\section{Data and methods}

\section{a. Total lightning}

For this study, total lightning observations (i.e., both intracloud and cloud-to-ground lightning) were provided by the ground-based Oklahoma Lightning Mapping Array (LMA; Rison et al. 1999; Thomas et al. 2004; MacGorman et al. 2008), with detection efficiency and range matching that of other LMAs installed in several regions across the United States (Fig. 1). This study builds on previous work using total lightning in operations (Patrick and Demetriades 2005; 


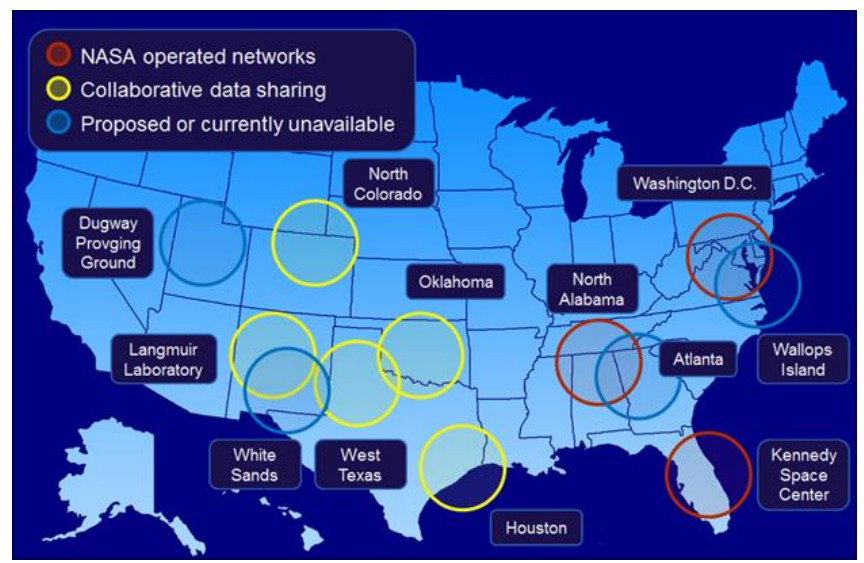

Figure 1. Locations of the current operational lightning mapping arrays (LMAs: red, NASA owned; yellow, collaborative partners), as well as networks that either are not accessible at this time or are proposed to be built (blue). Click image for an external version; this applies to all figures hereafter.

Nadler et al. 2009; Darden et al. 2010; White et al. 2012; Hodanish et al. 2013). Conceptually, LMAs are similar to the system developed by Lennon (1975) and further described by Maier et al. (1995). The LMA network detects very-high frequency (VHF) radiation sources as a developing lightning flash will emit electromagnetic radiation across a broad range of frequencies when charges are accelerated (Maggio et al. 2005). The LMAs map the sources using a time of arrival technique (Proctor 1971, 1981; Lennon 1975; Maier et al. 1995). The VHF source detections represent stepped leader formation of lightning during the early stage of a lightning flash before the visible return stroke, although VHF sources also can be observed after a return stroke. These VHF sources then can be used for various operational products in either their raw form (i.e., source densities) or recombined into flashes.

Total lightning has several abilities that previous assessments have found to be useful for forecast office operations (Bridenstine et al. 2005; Goodman et al. 2005; Demetriades et al. 2008; Nadler et al. 2009; Darden et al. 2010; Stano et al. 2011; Stano 2012; White et al. 2012). These abilities include total lightning's (i) relationship to a storm's updraft and (ii) high temporal resolution (1-2 $\mathrm{min})$, that when combined can aid in providing insight into whether a storm may become severe. Furthermore, total lightning provides additional situational awareness as it can aid in triaging which storms to investigate, as well as spatial information to aid with lightning safety. Assessments continue via ongoing activities between the National Aeronautics and Space Administration's
(NASA's) Short-term Prediction Research and Transition Center (SPoRT; Darden et al. 2002; Goodman et al. 2004) and its collaborative National Weather Service (NWS) partners, national centers [e.g., Aviation Weather Center (AWC), Storm Prediction Center (SPC), Operations Proving Ground, and Weather Prediction Center], the GOES-R Proving Ground (PG; Goodman et al. 2012), and the Hazardous Weather Testbed (HWT) in Norman, Oklahoma. Additional activities are supported by the University of Oklahoma-Cooperative Institute for Mesoscale Meteorological Studies, particularly in support of assessing the lightning jump algorithm (LJA) developed at the University of Alabama in Huntsville (Schultz et al. 2009, 2011).

Total lightning is not intended as a standalone tool. Its greatest use is to enhance situational awareness with higher temporal resolution than provided by radar volume-scan updates and to provide insight into the development of a storm's updraft. Increases (decreases) in total lightning indicate a strengthening (weakening) updraft (Lhermitte and Krehbiel 1979; Tessendorf et al. 2005; Kuhlman et al. 2006; Deierling et al. 2008). In the warning decision environment, subjectively analyzed lightning jumps are used to help forecasters determine whether to issue a warning. More recently, studies are investigating use of an automated LJA (Schultz et al. 2009, 2011; Calhoun et al. 2013b) to provide the same situational awareness benefits to forecasters, objectively. Forecasters also have begun using total lightning data for incident support. In this role, total lightning data have been used to reduce exposure of individuals to the lightning hazard. This has ranged from forecasters in the field (e.g., storm surveys), to outdoor workers (e.g., airport weather warnings), as well as supporting public safety for large, outdoor events. With the exception of this last application, these operational uses rely on the relationships of total lightning with updraft characteristics, mesocyclone development, and the vertical stretching of vorticity as outlined in the Introduction.

\section{b. Total lightning density products}

For the analysis of the 20 May 2013 Moore, Oklahoma, tornadic supercell, two total lightning products were used. Each was evaluated in the NWS's new decision support system, the Advanced Weather Interactive Processing System-II (AWIPS-II; Tuell et al. 2009), using NASA SPoRT's LMA data plug-in. The plug-in system for AWIPS-II provides flexibility 
as the legacy AWIPS-I system is rigid and each dataset had to conform to a preexisting format. In the case of total lightning, AWIPS-I had to be manipulated into accepting the data as model output. AWIPS-II plug-ins provide improved ingest and display options, streamlined data manipulation, and superior data visualizations. Unlike legacy AWIPS-I that required end users to make numerous file changes for each product from each LMA network, the AWIPS-II plug-in can be bundled as a single file that can be extracted on the system and will automatically update all required files. The LMA plug-in was designed to work with SPoRT's original LMA data format so that one data stream could support both legacy AWIPS-I and AWIPS-II end users simultaneously. Additionally, the LMA plug-in allows for greater flexibility in assigning domains, product resolutions, and product types.

The first product of this plug-in was the source density product (Goodman et al. 2005; Nadler et al. 2009; Darden et al. 2010; Stano et al. 2010b, 2012; White et al. 2012). This was the most basic total lightning display and was first used by SPoRT's partners at the Huntsville, Alabama, Weather Forecast Office (WFO) in 2003. It currently supports nearly a dozen forecast offices. The source density product is the sum of all sources in each $2 \mathrm{~km} \times 2 \mathrm{~km}$ horizontal grid box every $2 \mathrm{~min}$. Other partners use a $1 \mathrm{~km} \times 1$ $\mathrm{km}$ horizontal grid that updates every $1 \mathrm{~min}$. This article includes the source density product for familiarity with what is in operations at other WFOs. Currently, the operational community is moving towards an operational flash extent density product (Stano et al. 2010c, 2012) at the same spatial and temporal resolutions. The formation of the product is similar to that of the pseudo-GLM (PGLM) product described below. The primary difference with the PGLM is that the standard flash extent density product is used at 1- or 2$\mathrm{km}$ grid spacing.

The second product was NASA SPoRT's PGLM flash extent density (Stano et al. 2010b, 2011, 2012), which now incorporates eight collaborative LMAs. The SPoRT PGLM originally was developed in 2009 in discussions during that year's HWT Spring Program, and has evolved separately since then. The SPoRT PGLM product was designed to be a simple demonstration and training product for forecasters to prepare for the GLM that will be aboard GOES-R (Goodman et al. 2013). This product took the raw VHF sources from the ground-based LMAs and recombined them via a flash creation algorithm (McCaul et al. 2005, 2009). From there, the flashes were gridded on an $8 \mathrm{~km} \times 8 \mathrm{~km}$ grid to mimic the basic resolution of the GLM. The final PGLM flash extent density product counts the number of flashes that enter each grid box. Each flash was counted only once for any given grid box. The PGLM is the de facto training product for the GOES-R PG and has been used with the HWT's Spring Program since 2010 (Kingfield and Magsig 2009; Kuhlman et al. 2010; Stumpf et al. 2010). The NASA SPoRT version, including the LMA plug-in, was used in 2013. The SPoRT PGLM has been available to the AWC and SPC since 2012 (Stano et al. 2013). Beyond the PGLM serving as training for the GLM, the flash density provides some benefits over the source density product. The flash density products are less dependent on the range from the center of the LMA network. Source-to-flash clustering results in normalizing the detection efficiency and mitigating range effects, which in turn reduces apparent changes in storm strength that may occur by moving from lower to higher source detection efficiency locations, and vice versa. Also, the flash density product is more intuitive to use because an end user immediately understands that a density of five means five flashes have occurred, whereas a source density of 100 could result from a single flash or multiple flashes. The ambiguity in source density is due to a single flash being composed of multiple sources, which can vary widely in number depending on the spatial length of the flash and the location of the flash relative to the network.

\section{c. Total lightning tracking tool}

Beyond the source density and PGLM products, this analysis also used NASA SPoRT's total lightning tracking tool (TLTT), which was collaboratively developed with the National Oceanic and Atmospheric Administration (NOAA)/NWS Meteorological Development Laboratory (MDL). The basic concept was the same as used by earlier interactive display systems, such as MDL's System for Convection Analysis and Nowcasting (Smith et al. 1998) and the Lightning Imaging Sensor Data Application Display (Boldi et al. 1998; Weber et al. 1998), which relied on the NOAA/National Severe Storms Laboratory (NSSL) Storm Cell Identification and Tracking algorithm (Johnson et al. 1998). The TLTT was developed for total lightning data in response to NWS forecaster feedback requesting the ability to visualize the time series of total lightning observations associated with individually tracked storms in real-time. Currently, 
NWS forecasters must mentally assemble a time series by applying the AWIPS sampling tool to each individual storm. AWIPS-II's ability to accept custom plugins will enable forecasters to incorporate SPoRT's TLTT. To use this tool, a forecaster selects a storm of interest and indicates the storm's path. The tool then generates a pop-up display of the time series. The TLTT was first evaluated in the 2013 HWT Spring Program. During the HWT evaluation, the TLTT was difficult to implement for slow-moving storms. In AWIPS-II, the TLTT shows the entire storm track highlighted by the forecaster. For slow storms, this would obscure the actual total lightning data as the cell-track points can get plotted over one another. Additionally, forecasters noted difficulty initiating the TLTT if it was not added to the display at the first time it was loaded in AWIPS-II. Forecasters also requested a fixed $y$ axis on the pop-up display, as opposed to a dynamic $y$ axis that adjusted to the magnitude of the observed total lightning. Based on this feedback, the TLTT was adjusted for the Operations Proving Ground and HWT evaluations in spring 2014. The adjustments are included with additional enhancements as the new tool handles most types of gridded, radar, and other meteorological observations as part of the broader MDL automated moving trace tool.

\section{d. The lightning jump algorithm}

The LJA compared the present time rate of change of the total flash rate against the recent flash rate history of the storm. The current version of the algorithm was developed and tested by Schultz et al. (2009, 2011). This algorithm has been tested empirically on a large set of thunderstorms in multiple regions of the country and is described in detail in the appendix. A jump was defined whenever the present total flash rate exceeded 10 flashes $\min ^{-1}$ and the present time rate of change in the flash rate was more than two standard deviations $(2 \sigma)$ above the storm's change in flash rate for the past $12 \mathrm{~min}$. The $2 \sigma$ configuration has provided the best skill scores compared to other configurations (Schultz et al. 2009, 2011) given the environmental and regional variability in the flash rates of storms (e.g., the high plains versus the East Coast versus the Intermountain West; Boccippio et al. 2001). When the LJA was triggered, it signified a large increase in that storm's updraft [e.g., Fig. 5 from Wiens et al. (2005), Figs. 5 and 6 from Deierling and Petersen (2008), and Fig. 10 from Calhoun et al. (2013a)], which tended to increase the storm's potential for producing severe weather.
The LJA currently is being evaluated for possible future NWS use by both the University of Alabama in Huntsville and the NSSL, with support from several other organizations (Calhoun et al. 2013b). For this paper, the algorithm was run twice. The first was run at Huntsville in a pure, post-event mode. The second run was performed at the NSSL in Norman, Oklahoma. This run used the same LJA, but with a realtime data feed and automated cell tracking. As noted later in the paper, the two runs gave slightly different times for the lightning jumps, which is due to the LJA's dependence on how a storm cell is tracked. Note that forecast offices with access to total lightning data for their regions of responsibility (e.g., Huntsville, Sterling, and Melbourne) have looked subjectively for lightning jumps for severe storm assessment. The TLTT is intended to make it easier for a forecaster to observe lightning jumps and may eventually incorporate the LJA for automated identification.

\section{Analysis}

\section{a. Pre-storm environment}

The events of 20 May 2013 were well forecasted, both from the national perspective at the SPC down to the local Norman, Oklahoma, WFO. The environment was very favorable for tornadic supercell formation, as indicated by the SPC's convective outlooks. Central Oklahoma was highlighted as far back as the Day 6 outlooks, with the SPC discussion stating that "...day 6 may be the day of highest tornado potential...." On Sunday, 19 May, the day before the event, the 0600 UTC outlook indicated a moderate risk for central Oklahoma, and the moderate risk status was maintained throughout the event. Similar awareness was demonstrated in the Norman WFO's Hazardous Weather Outlooks dating back to 15-16 May.

On the morning of the event, the environment over central Oklahoma was quite favorable for supercells. The 1200 UTC Norman, Oklahoma, sounding (Fig. 2a) indicated a $0-1-\mathrm{km}$ storm relative helicity $(\mathrm{SRH})$ of $308 \mathrm{~m}^{2} \mathrm{~s}^{-2}$ while surface-based CAPE was $1920 \mathrm{~J}$ $\mathrm{kg}^{-1}$. Effective bulk shear was about $25 \mathrm{~m} \mathrm{~s}^{-1}$ while lapse rates were $5.8^{\circ} \mathrm{C} \mathrm{km}^{-1}$ for the lowest $3 \mathrm{~km}$ and $7.0^{\circ} \mathrm{C} \mathrm{km}^{-1}$ for the 3-6-km layer (using the convention of $-\mathrm{dT} / \mathrm{dz}$ ). An intermediate sounding at 1800 UTC (Fig. 2b) revealed that surface-based CAPE increased to around $3100 \mathrm{~J} \mathrm{~kg}^{-1}$, with the most-unstable CAPE near $4900 \mathrm{~J} \mathrm{~kg}^{-1}$. The SRH in the $0-1 \mathrm{~km}$ layer decreased to $131 \mathrm{~m}^{2} \mathrm{~s}^{-2}$. The lapse rate from the surface to $6 \mathrm{~km}$ increased to $7.6^{\circ} \mathrm{C} \mathrm{km}^{-1}$. Moreover, Oklahoma 

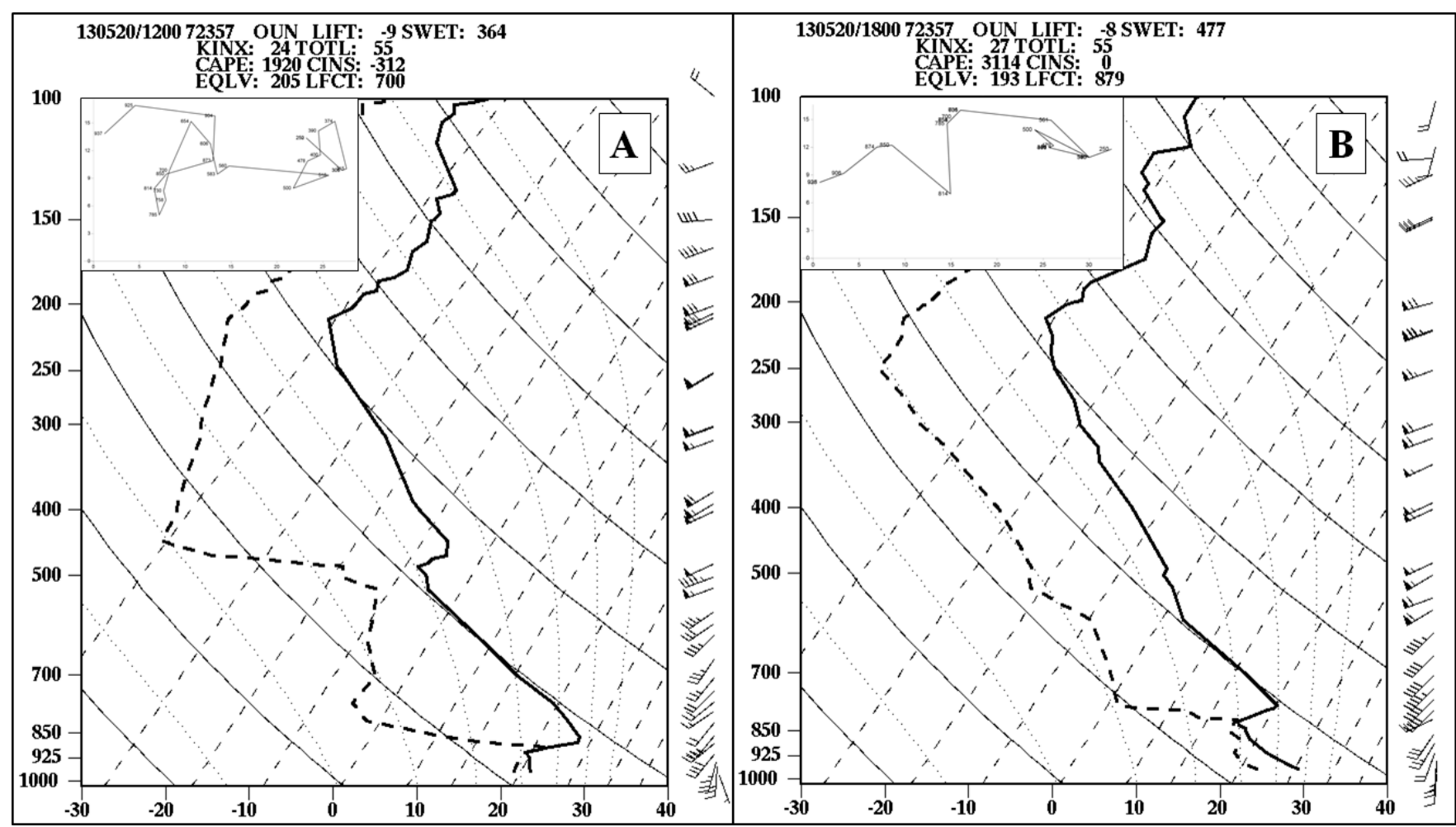

Figure 2. Observed soundings from Norman, OK, on 20 May 2013 at (a) 1200 UTC and (b) 1800 UTC. Embedded hodographs are courtesy of the University of Wyoming upper-air archive.

Mesonet data (www.mesonet.org/index.php/) indicated that a quasi-stationary front was oriented southwestnortheast and intersected a strong dryline west of the Oklahoma City metropolitan area. Through $850 \mathrm{hPa}$, winds were out of the south-southwest at $15 \mathrm{~m} \mathrm{~s}^{-1}$, advecting moisture northward from the Gulf of Mexico. At $500 \mathrm{hPa}$, moderately strong cyclonic vorticity was observed. This was coincident with $10 \mathrm{~m} \mathrm{~s}^{-1}$ (20 kt) of speed divergence over eastern Oklahoma as a speed maximum approached from the west and a short-wave trough ejected into the southern Great Plains. Diffluence was evident in eastern Oklahoma at $300 \mathrm{hPa}$. These observations suggested energy and forcing were available to sustain this particular severe weather event.

\section{b. Total lightning perspective of the Moore, Okla- homa, tornadic supercell}

This section focuses on the use of NASA SPoRT's plug-in for displaying total lightning in conjunction with the utility of the TLTT in AWIPS-II. Our analysis began just prior to convective initiation that occurred at 1851 UTC in the vicinity of Chickasha, Oklahoma (Fig. 3a). These cells developed in the immediate vicinity of an intersection of the dryline bulge and stationary front, which was noted just to the west of the new convection. By 1904 UTC, the two clusters of cells appeared as a disorganized group of weak echoes from shower activity roughly halfway between Chickasha and Moore, Oklahoma (Fig. 3b). Then at 1908 UTC, one of the more northern cells in this cluster became dominant, and its low-level reflectivity increased (Fig. 3c). By 1912 UTC, the storm continued its development as low-level reflectivity increased (Fig. 3d). It was at this time that the NWS in Norman, Oklahoma, issued its first severe thunderstorm warning for this storm.

A comparison of Figs. 4 and 5 shows how total lightning activity rapidly increased in a 2-min time period between 1908 and 1910 UTC. The source density product (upper left) is used by several SPoRT partners in operations; the flash extent density product (upper right) uses PGLM data, which SPoRT is providing to various end users to demonstrate future GLM capabilities. The pop-up windows show timeseries products with the SPoRT/MDL TLTT, and corresponds to the source density (a) and PGLM flash extent density (b) products.

Because current capabilities available to forecast offices do not include an objective automated LJA, 


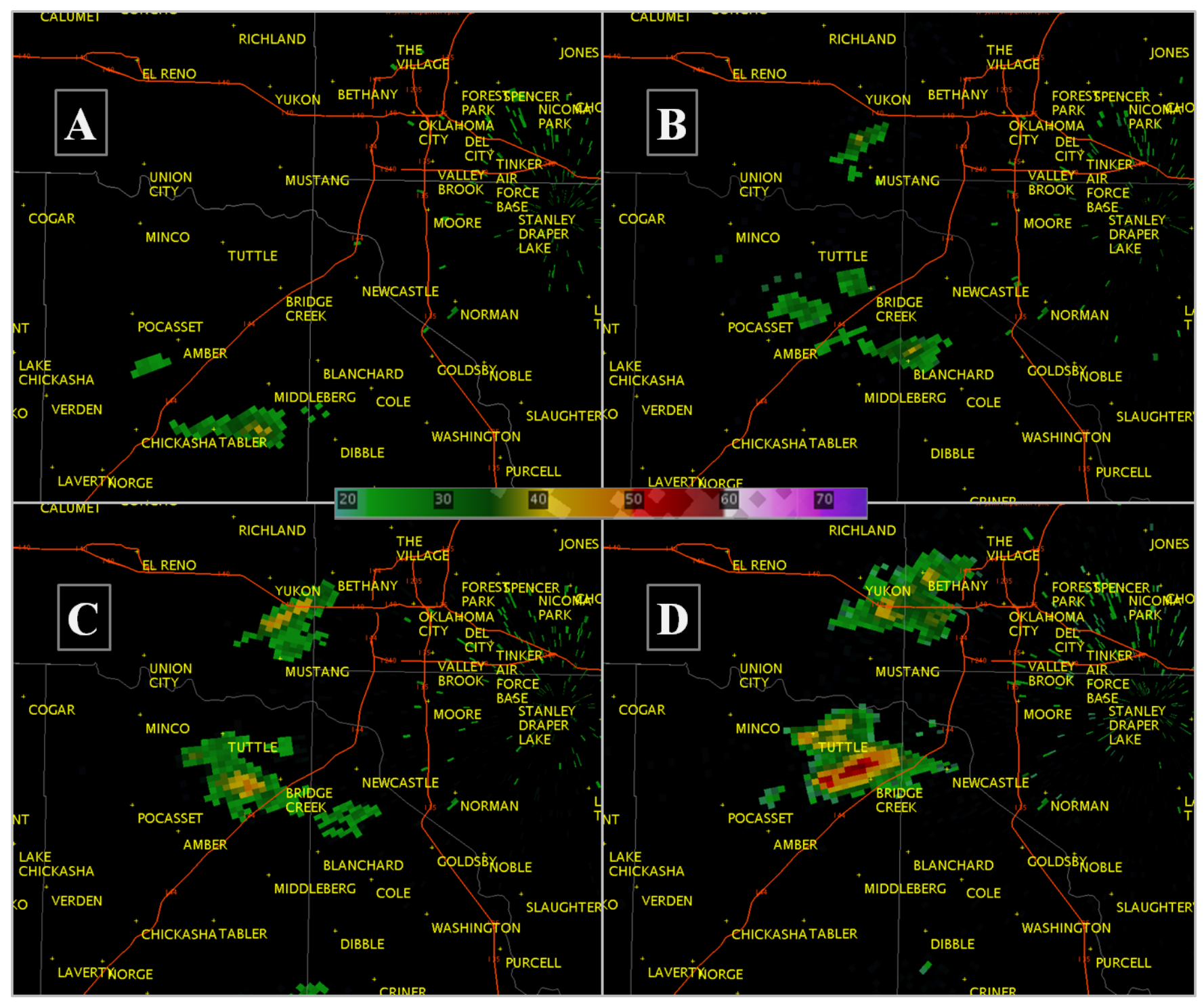

Figure 3. Base-scan $\left(0.5^{\circ}\right.$ elevation) reflectivity (dBZ) in central OK from the Oklahoma City (KTLX) Doppler radar on 20 May 2013 at (a) 1851 UTC, (b) 1904 UTC, (c) 1908 UTC, and (d) 1912 UTC.

lightning jumps presently have to be interpreted subjectively. Subjectively, a lightning jump is described as a rapid increase in total lightning within a short period of time, usually $2 \mathrm{~min}$. A rough rule of thumb that is used is for the source density to exceed a minimum source density value of 100 sources. With these guidelines, the first lightning jump was identified at 1908 UTC (Fig. 4), and was obvious by 1910 UTC in both the source density and PGLM flash extent density (Fig. 5). Here the values reached about 800 sources and 46 flashes $\mathrm{min}^{-1}$, respectively.

Even though the objective LJA, based on Schultz et al. (2011), was not available operationally, it was run for this event for comparison. Figure 6 shows when the LJA detected lightning jumps with respect to the time of the Moore, Oklahoma, tornado. Note that there were differences between the subjective analysis versus the LJA (Fig. 6). In the subjective analysis, the largest, 1-min PGLM value in an $8 \mathrm{~km} \times 8 \mathrm{~km}$ grid box over the cell of interest was used. Meanwhile, the LJA used the flash rate of the entire storm cell, as determined by an objective cell tracker. Therefore, the flash rate for the entire cell was greater than that for a single grid point (e.g., Fig. 6 versus Fig. 5 at 1910 UTC). As a result of this difference, the lightning jumps were observed at slightly different times. However, the subjective analysis and LJA were very close, with the LJA observing the initial lightning jump 3 min later at 1911 UTC. 


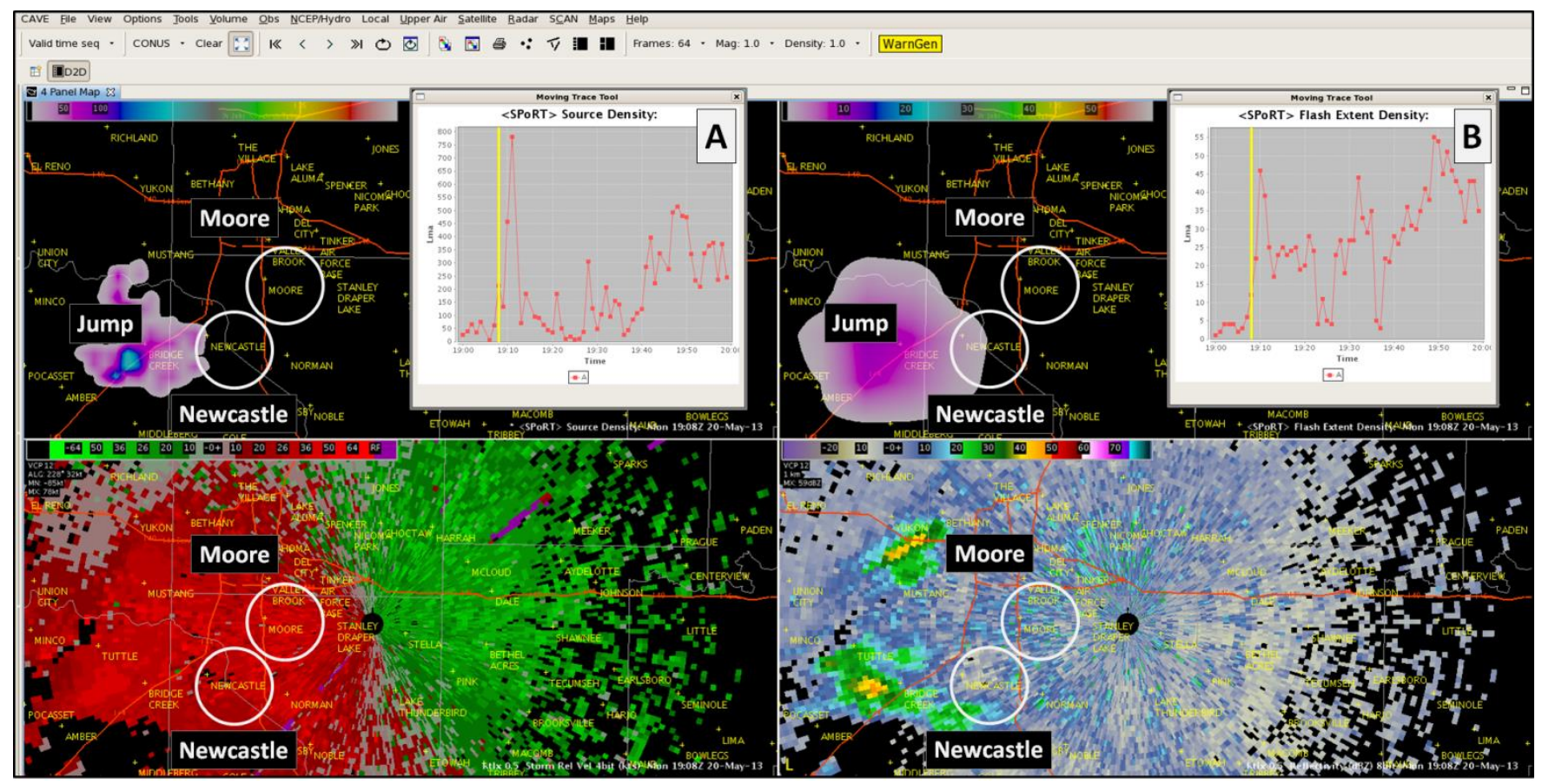

Figure 4. An AWIPS-II four-panel display from 1908 UTC 20 May 2013 showing the OK LMA VHF source density (upper left, sources $\mathrm{km}^{-2} \mathrm{~min}^{-1}$ ), PGLM flash extent density (upper right, flashes $64 \mathrm{~km}^{-2} \mathrm{~min}^{-1}$ ), storm-relative radial velocity (lower left, kt), and reflectivity (lower right, dBZ) - the latter two from the KTLX WSR-88D radar at $0.5^{\circ}$. The total lightning tracking tool output is shown in the inset windows for (a) source densities and (b) PGLM flash extent densities. The white circles highlight the locations of Moore and Newcastle, OK. The yellow vertical line in each inset window indicates where in time the trace tool is with respect to the AWIPS-II display.

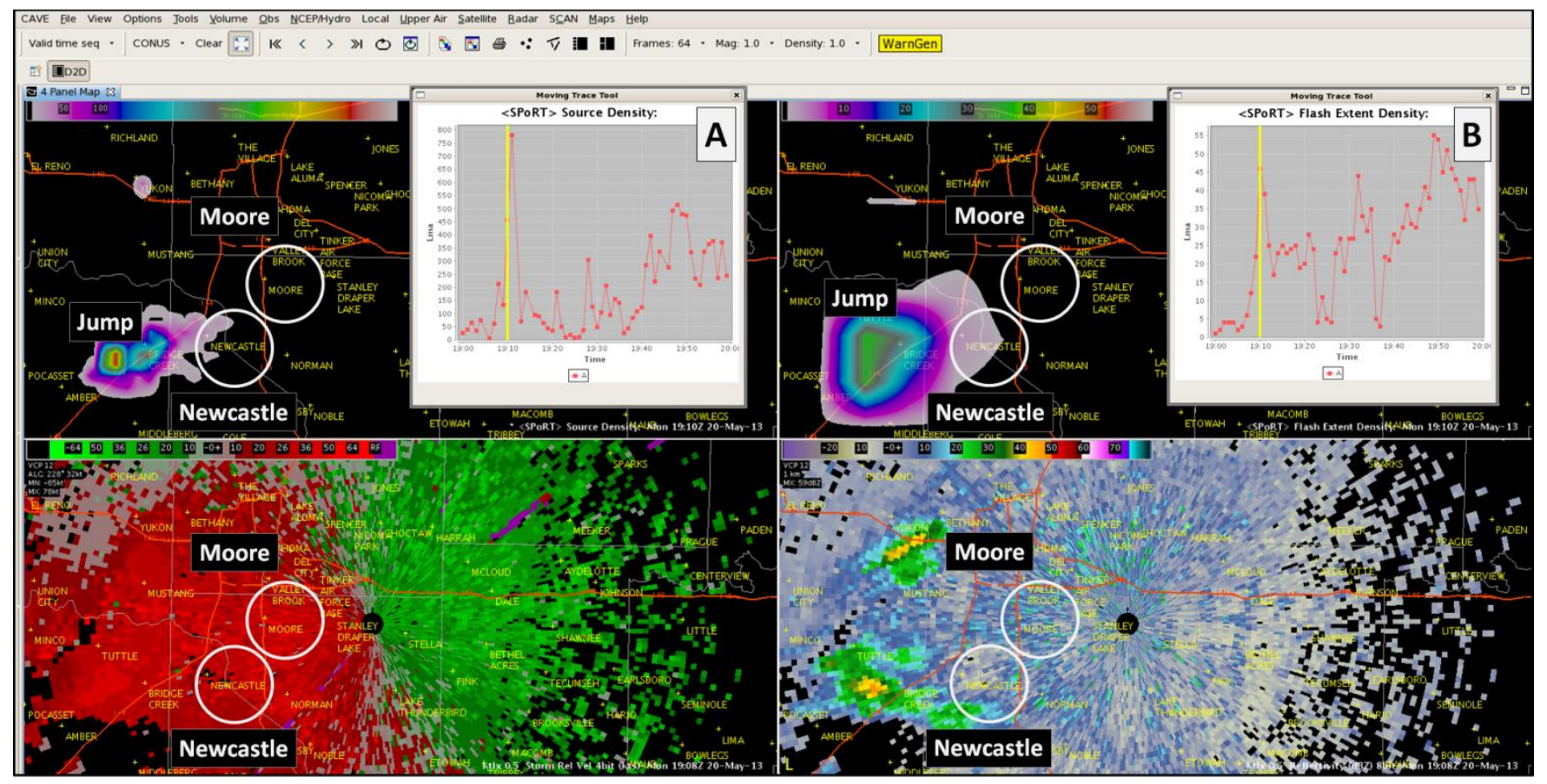

Figure 5. Same as Fig. 4 except for 1910 UTC.

To put this jump in the context of other storm data, the jump's initial appearance at 1908 UTC and its rapid increase to a peak in PGLM flash extent density at 1910 UTC indicated the updraft was rapidly strengthening as the upward vertical motion in the mixed-phase region likely was increasing rapidly. The 


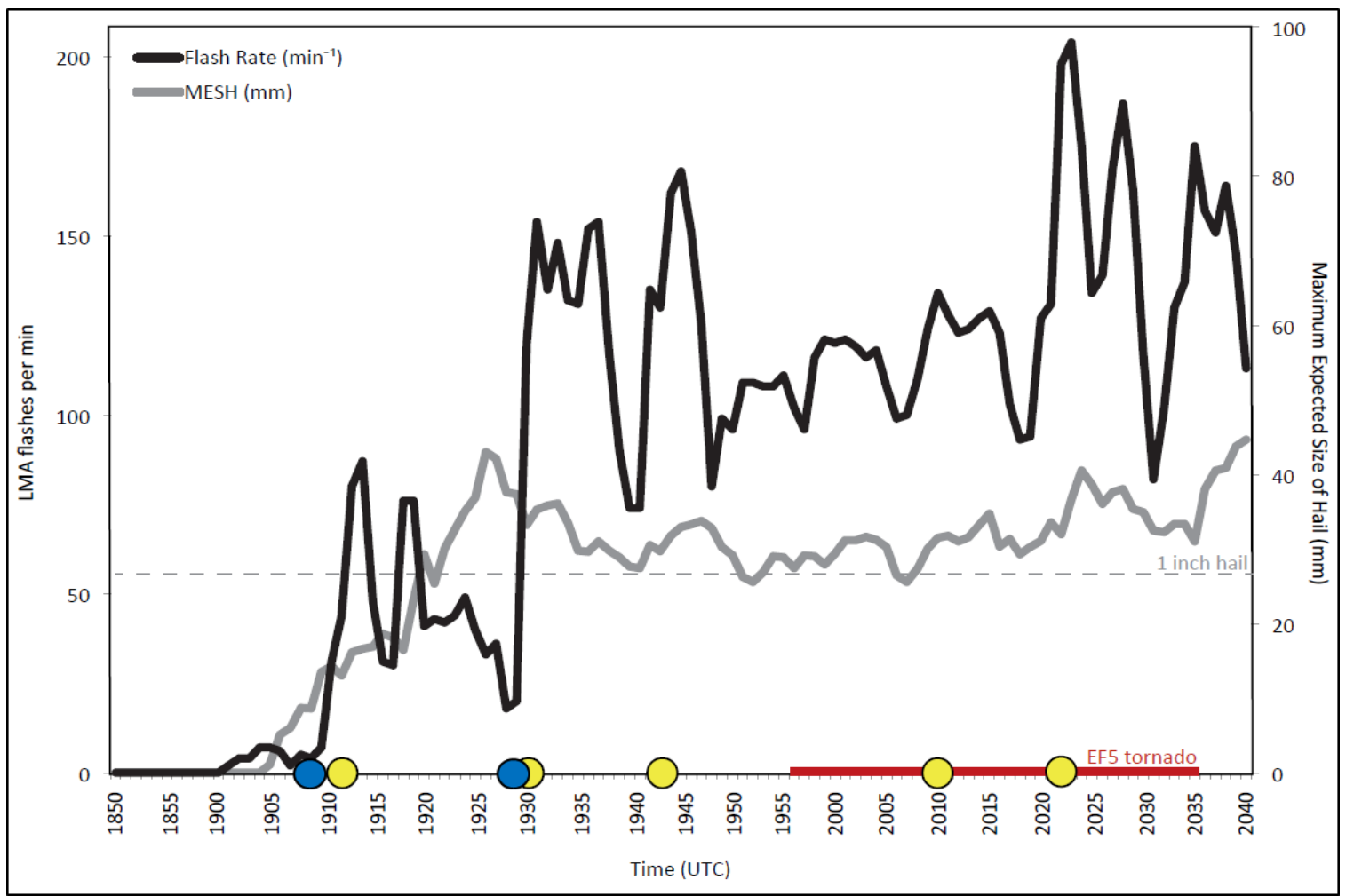

Figure 6. A time series plot of the Moore, OK, supercell's flash rate (black line, $\mathrm{min}^{-1}$ ) in comparison to the maximum estimated size of hail (MESH, mm, gray line). The lightning jumps, as determined by the lightning jump algorithm, are shown as yellow circles (simulated real-time OK run) and blue circles (post-event Huntsville run). The red line shows the duration of the tornado produced by the parent supercell. Note that the variability in the flash rate is real and not an artifact of the OK LMA. The network (i) requires a minimum of 6 stations to observe total lightning and (ii) maintained 14-16 of 19 stations from 1900 to 2000 UTC. The drop at 1937 UTC did come while the network had fewer sensors active, but still had enough sensors to reasonably indicate that the lightning activity had diminished.

initial jump in the total lightning flash rate from the LJA (Fig. 6) preceded a slower, steadily increasing trend in the maximum expected size of hail (MESH; Cintineo et al. 2012), as determined from multi-radar, multi-sensor grids associated with the developing supercell. From 1912 to 1922 UTC, midlevel rotation developed as inferred from the azimuthal shear plot (Fig. 7), and a mesocyclone was detected on radar at 1917 UTC by the official NWS algorithm. The MESH remained $>2.54 \mathrm{~cm}$ ( 1 in) for the duration of the analysis period after 1920 UTC. This was smaller than the observed maximum hail size, but individual errors can exist, particularly when comparing 1-to-1 size information. However, MESH was used here to estimate the timing of the hail and severe hail. At 1927 UTC, $8.2-\mathrm{cm}$ hail was reported in Yukon, Oklahoma-19 min after the initial rapid intensification and first lightning jump, as shown subjectively by the source density and PGLM flash extent density products and automated LJA. Also, $2.5-\mathrm{cm}$ hail was observed at Will Rogers Airport at 1928 UTC.
The radar data closest to the time of the reinforcing lightning jump (1928 UTC) are shown in Fig. 8. This jump was apparent in both the source density and PGLM flash extent density. The term "reinforcing" was adapted from the discussion of the LJA by Schultz et al. (2009, 2011). There, a lightning jump is active for $30 \mathrm{~min}$. The second lightning jump at 1928 UTC occurred $20 \mathrm{~min}$ after the initial lightning jump. As this initial lightning jump was still considered active, this second lightning jump demonstrates that the storm still was likely to produce severe weather, thus reinforcing the original's observation. By comparison, the time analyzed by the current developmental version of the LJA indicated the lightning jump 2 min later at 1930 UTC (Fig. 6). Like the initial lightning jump for this storm, the subjective approach and objective LJA were in good agreement. The difference in time primarily was due to the LJA using the storm's flash rate, as outlined in Schultz et al. (2011). 


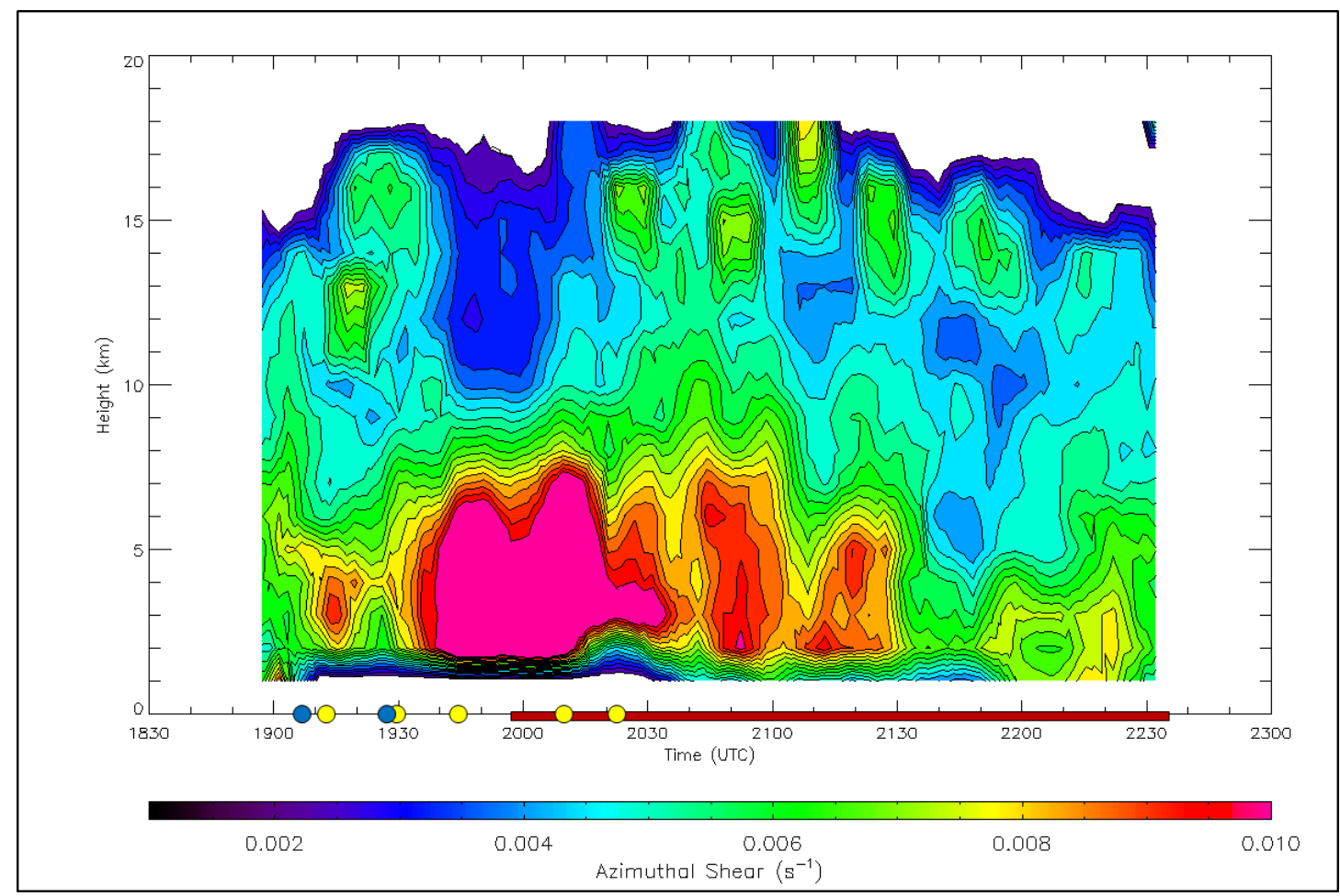

Figure 7. Time-height plot of maximum azimuthal shear at each altitude in 1-km increments from 1856 to 2232 UTC. The image is a $1 \mathrm{~km} \times 1 \mathrm{~km} \times 1 \mathrm{~km}$ composite of radar observations from the four closest radars to the storm: KTLX; Vance Air Force Base, OK; Frederick, OK; and Tulsa, OK. The colored circles along the time axis indicate the times that the LJA observed lightning jumps: blue (post-event Huntsville run) and yellow (simulated real-time OK run). The horizontal red line on the $x$ axis indicates the relation of the lightning jumps and maximum azimuthal shear to the time that the Moore, OK, tornado occurred.

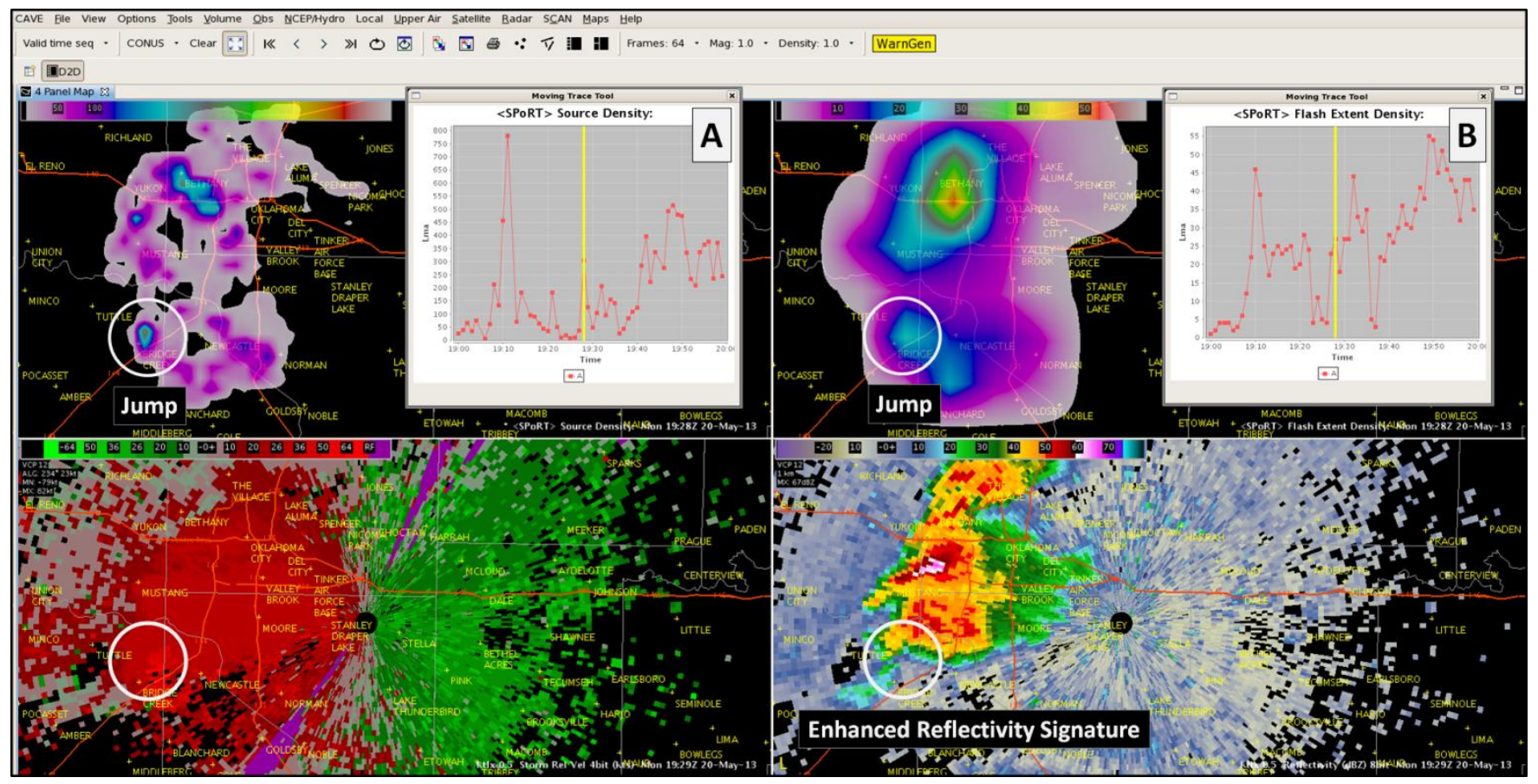

Figure 8. Same as Fig. 4 except for 1928 UTC. The white circles indicate the object being tracked for the time series of total lightning observations. 
This reinforcing jump indicated a second surge in updraft strength in the mixed-phase region and, as described in the Introduction, suggested that the mesocyclone also was strengthening. Thus, it flagged the storm for additional forecaster attention. Between 1928 and 1935 UTC, the low-level rotation within the storm strengthened and deepened (Fig. 7), and the maximum height of the 50-dBZ echo increased to 17 km (Fig. 9). Together, this combination of lightning and radar indicators suggested to a forecaster that the storm continued to intensify and the probability of a tornado was increasing, particularly given the nearstorm environment. The radar reflectivity display in the AWIPS-II four-panel (Fig. 8) also emphasized the tornadic potential, as a hook echo had formed. This reinforcing lightning jump occurred $26 \mathrm{~min}$ before the first report of a tornado at 1956 UTC near Newcastle, Oklahoma. Based on radar observations, a tornado warning was issued at 1940 UTC for the storm that ultimately produced a tornado in Newcastle and Moore, Oklahoma.

At 1950 UTC, radar observations showed a classic hook echo and velocity-couplet signatures (Fig. 10). Both total lightning products displayed pronounced maxima, with the source density product indicating over 500 sources while the PGLM flash extent density product was within $1 \mathrm{~min}$ of its largest value for the entire period (55 flashes in $1 \mathrm{~min}$ ). These increasing values implied that the updraft still was intensifying, and given the radar signatures and near-storm environment, the tornado threat could be considered quite high.

\section{Discussion and conclusions}

On 20 May 2013, known thermodynamic and kinematic parameters favorable for tornadoes were in place over central Oklahoma (Thompson et al. 2003). Additionally, favorable low-level forcing was in place with a stationary front intersecting a sharp dryline (Markowski et al. 1998; Rasmussen et al. 2000). With the environment being this favorable, forecasters were on heightened alert for any developing storm. This study showed that the total lightning observations would have given forecasters additional confidence in identifying where convection was forming and intensifying. Furthermore, the 1-min update of the total lightning observations (source density or PGLM) would have filled the gap to indicate rapid growth between radar volume scans as the storm rapidly intensified. In particular, two lightning jumps occurred at approximately 1908 and 1928 UTC, respectively. These lightning jumps signified that the updraft was intensifying, particularly in the mixed-phase region where observations and models suggest that the majority of a storm's charge is produced (e.g., Williams et al. 1999; Lang and Rutledge 2002; Kuhlman et al. 2006; Deierling and Petersen 2008; Calhoun et al. 2013a). Following both lightning jumps, the magnitude of azimuthal shear increased and regions of larger shear increased in depth (Fig. 7) as the mesocyclone intensified. In combination with the increase in updraft inferred from the lightning jump, this likely indicated increased vertical stretching of vorticity.

In this case, the total lightning observations matched the conceptual model described in the Introduction; i.e., rapid increases of total lightning suggest a strengthening of the storm's updraft in the mixed-phase region and precede both mesocyclone development and severe weather. Rapid increases of total lightning were observed in advance of reported severe weather. The lightning jump at approximately 1908 UTC (subjectively determined as would be done in a local forecast office) and 1911 UTC (objectively determined by the LJA) preceded the first severe weather generated by the supercell by almost $20 \mathrm{~min}$ (8.2-cm hail in Yukon, Oklahoma, at 1927 UTC). This first lightning jump also preceded a slow increase in the MESH (Fig. 6). The second, reinforcing lightning jump at 1928 UTC (subjective) and 1930 UTC (LJA) preceded the initial report (1956 UTC) of the tornado that would later impact Moore, Oklahoma, by 28 and 26 min, respectively. A pronounced peak in VHF source densities and the PGLM flash extent density occurred 6-8 $\mathrm{min}$ before the tornado. The LJA observed an additional reinforcing lightning jump at 1943 UTC, which was $13 \mathrm{~min}$ before touchdown. These lightning jump lead times compare favorably with the results of Schultz et al. (2011), who studied severe weather reports relative to automated lightning jumps in 711 thunderstorms having various convective modes in four regions across the United States (e.g., northern Alabama; Washington, DC; eastern Colorado-western Kansas; and Oklahoma). When total lightning was used, Schultz et al. (2011) found that a lightning jump preceded the subsequent severe weather report by an average of $20.7 \mathrm{~min}$, with $\sigma=$ $\pm 15.0 \mathrm{~min}$. When cloud-to-ground lightning was used alone, however, Schultz et al. (2011) found that the lead time tended to be much less, averaging $13.5 \mathrm{~min}$, with $\sigma= \pm 15.1 \mathrm{~min}$. 


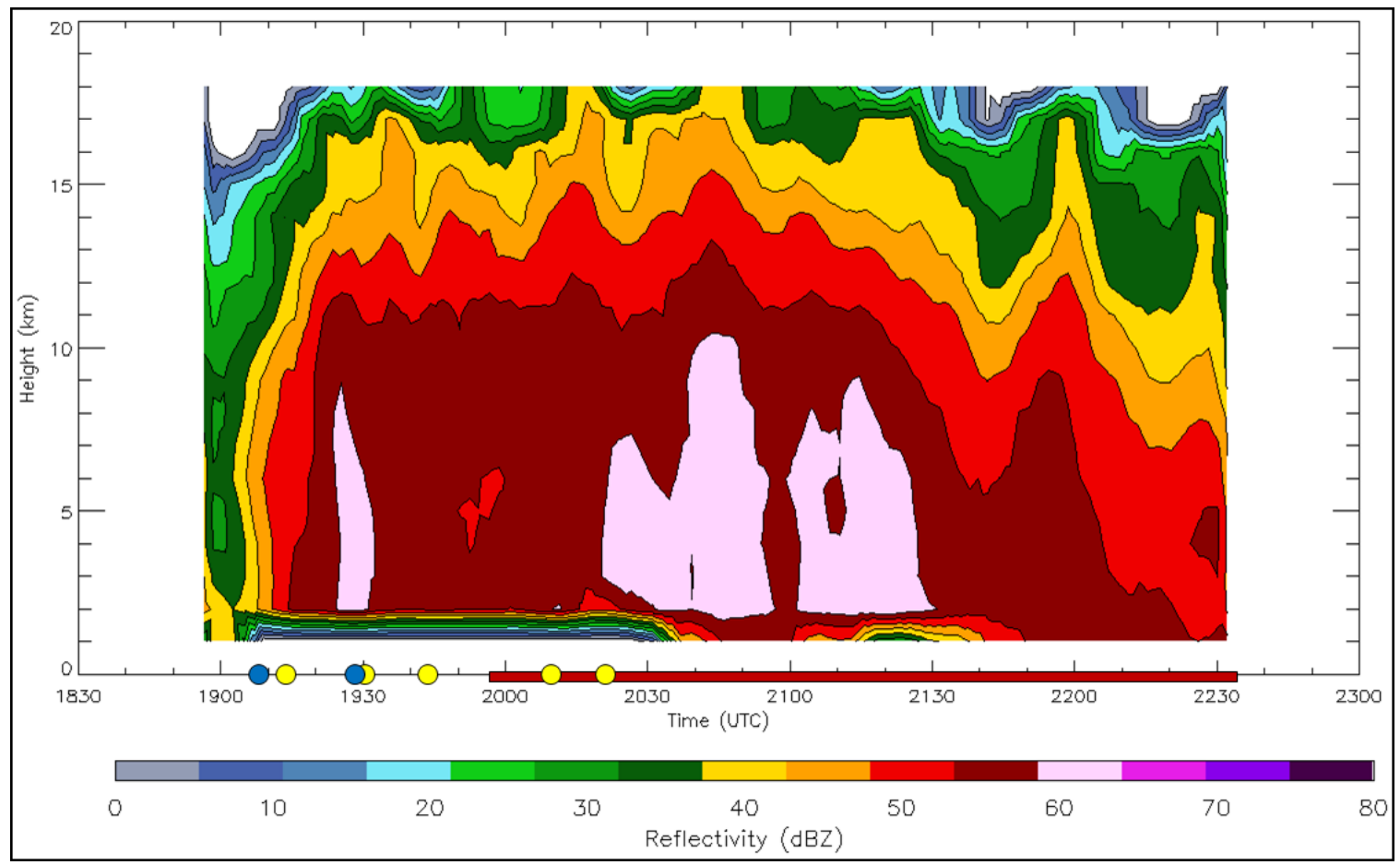

Figure 9. Same as Fig. 7 except for the maximum radar reflectivity.

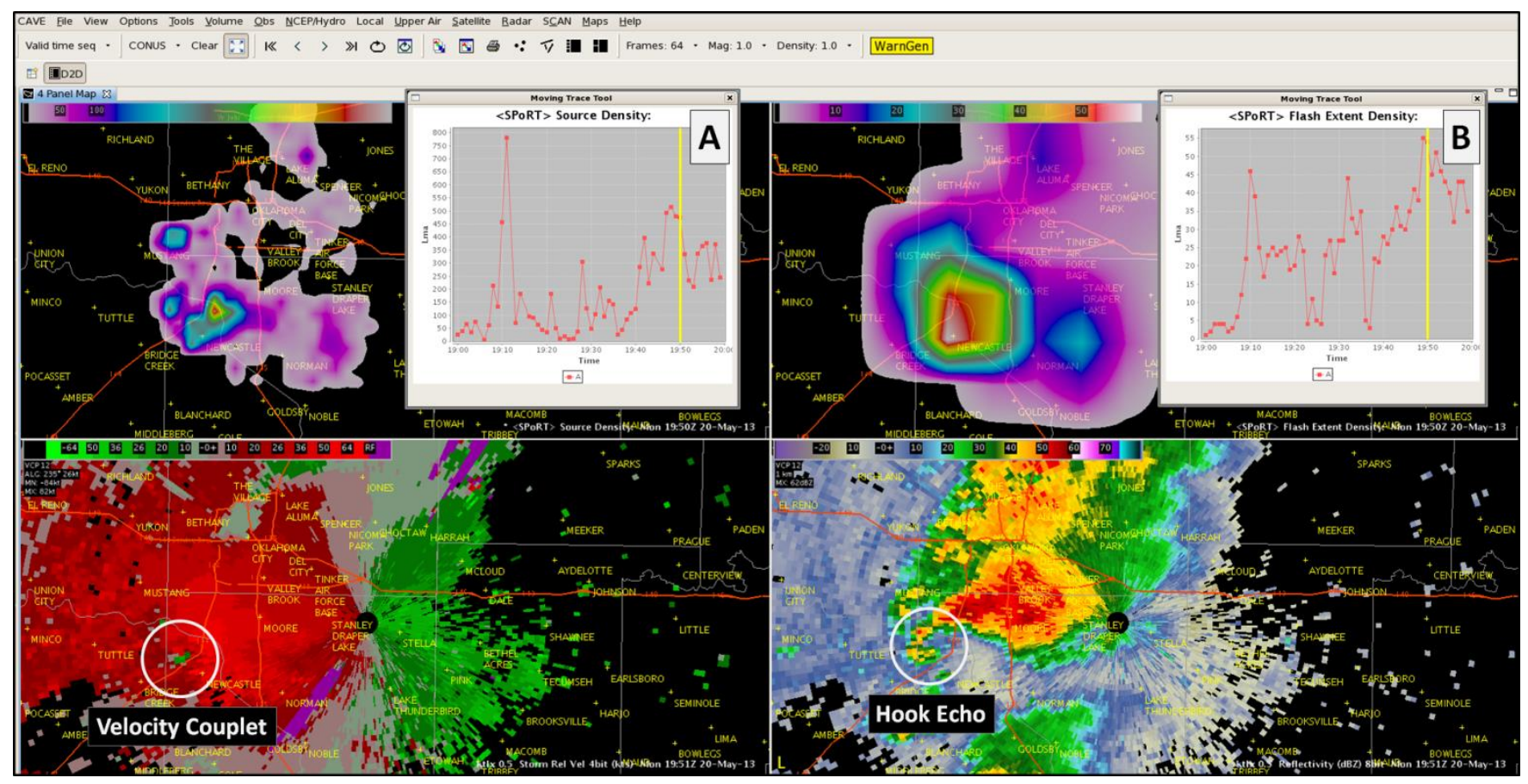

Figure 10. Same as Fig. 4 except for 1950 UTC. The white circles highlight the mesocyclone region of the supercell.

Similar results have been found for severe weather cases in which total lightning observations have been used subjectively in NWS operations to provide additional insight into a storm's evolution (e.g., Darden et al. 2010; White et al. 2012; Hodanish et al.
2013). On the day of the 2 March 2012 tornado outbreak in northern Alabama (White et al. 2012), for example, the forecaster in the Huntsville WFO knew that the environment was favorable for supercell storms and was looking for additional information to 
confirm the decision to issue a warning. Lightning data enabled the forecaster to issue a warning several minutes before the next radar volume scan arrived.

These studies-along with the Moore, Oklahoma, tornadic supercell analysis presented herein-suggest several conclusions. First, total lightning observations will make an important addition to the use of radar data in forecast offices to help increase confidence in warning operations. This improved confidence could gain precious minutes for severe weather warnings. Second, this confidence can be enhanced with tools to track and visualize time-series trends of total lightning in storms as well as the development of an automated LJA. Each of these capabilities will be enhanced in the $G O E S-R$ era with the routine availability of GLM data.

Acknowledgments. The authors thank the GOES-R Program for funding and the collaborations with NOAA's HWT and NSSL for the ongoing evaluations of the LJA, the TLTT, and for the support to the operations and maintenance of the Oklahoma LMA and NASA SPoRT's GOES$R$ PG activities. The authors also wish to thank all of the individuals involved in the development of the LJA by the University of Alabama in Huntsville, NASA's Earth Science Office, and collaborations with the NSSL.

\section{APPENDIX}

\section{The 2 $\sigma$ Lightning Jump Algorithm}

The $2 \sigma$ algorithm (Schultz et al. 2009, 2011) is a multiple-step process that uses the $14 \mathrm{~min}$ of the most recent flash history of a thunderstorm to identify when thunderstorm intensification is ongoing. The first step is combining two 1-min flash periods and averaging them over a 2-min period for the oldest $12 \mathrm{~min}$ of the $14 \mathrm{~min}$ of flash data,

$$
F R_{-} \operatorname{avg}\left(t_{i}\right)=\frac{F R\left(t_{i}\right)+F R\left(t_{i-1}\right)}{2} .
$$

where $F R \_a v g\left(t_{i}\right)$ is the average flash rate at time $t_{i}$ for times $t_{i}$ and $t_{i-1}$. This step filters some of the noise associated with the total lightning dataset, and has been shown to be the most effective time-averaging technique by Gatlin and Goodman (2010). Next, a time rate of change of the flash rate $(D F R D T)$ is calculated.

$$
\operatorname{DFRDT}\left(t_{i}\right)=\frac{F R_{-} a v g\left(t_{i}\right)-F R_{-} \operatorname{avg}\left(t_{i-2}\right)}{t_{i}-t_{i-2}}
$$

Third, $\sigma$ is calculated based on the five most recent DFRDT values calculated from these $12 \mathrm{~min}$ of data. Twice this value determines the jump threshold.

When the next 2 min of flash data are collected, they are combined using Eq. (1) and then a new DFRDT value is calculated using Eq. (2). If this DFRDT value exceeds the $2 \sigma$ value and the total flash rate is $>10$ flashes $\mathrm{min}^{-1}$, then a jump has been identified. This process is repeated as new data are obtained until the storm dissipates.

\section{REFERENCES}

Adlerman, E. J., K. K. Droegemeier, and R. Davies-Jones, 1999: A numerical simulation of cyclic mesocyclogenesis. J. Atmos. Sci., 56, 2045-2069, CrossRef.

Bluestein, H. B., 1993: Synoptic-Dynamic Meteorology in Midlatitudes. Volume II: Observations and Theory of Weather Systems. Oxford University Press, 594 pp.

Boccippio, D. J., K. L. Cummins, H. J. Christian, and S. J. Goodman, 2001: Combined satellite- and surface-based estimation of the intracloud-cloud-to-ground lightning ratio over the continental United States. Mon. Wea. Rev., 129, 108-122, CrossRef.

Boldi, R., E. Williams, A. Matlin, M. Weber, S. Hodanish, D. Sharp, S. Goodman, and R. Raghavan 1998: The design and evaluation of the Lightning Imaging Sensor Data Applications Display (LISDAD). Preprints, 19th Conf. on Severe Local Storms, Minneapolis, MN, Amer. Meteor. Soc., 631-634.

Bridenstine, P. V., C. B. Darden, J. Burks, and S. J. Goodman, 2005: The application of total lightning data in the warning decision making process. Preprints, Conf. on Meteorological Applications of Lightning Data, San Diego, CA, Amer. Meteor. Soc., P1.2. [Available online at ams.confex.com/ams/pdfpapers/ 83037.pdf.]

Calhoun, K. M., D. R. MacGorman, C. L. Ziegler, and M. I. Biggerstaff, 2013a: Evolution of lightning activity and storm charge relative to dual-Doppler analysis of a high-precipitation supercell storm. Mon. Wea. Rev., 141, 2199-2223, CrossRef.

, and Coauthors, 2013b: Implementation and evaluation of a real-time lightning jump algorithm for operational use. Preprints, 38th Annual Meeting, North Charleston, SC, Natl. Wea. Assoc. [Available online at www.nwas. org/meetings/nwa2013/agenda/.]

Christian, H. J., Jr., 2006: Geostationary Lightning Mapper (GLM). Preprints, Second Conf. on Meteorological Applications of Lightning Data, Atlanta, GA, Amer. Meteor. Soc., J2.3. [Available online at ams.confex. com/ams/Annual2006/webprogram/Paper105471.html.] , R. J. Blakeslee, and S. J. Goodman, 1989: The detection of lightning from geostationary orbit. $J$. Geophys. Res., 94, 13329-13337, CrossRef. , and 1992: Lightning Imaging Sensor (LIS) for the Earth Observing System. Tech. Rep. TM4350, NASA, Washington, DC, $44 \mathrm{pp}$. [Available from Center for Aerospace Information, P.O. Box 8757, Baltimore, MD 21240.] 
Cintineo, J. L., T. M. Smith, V. Lakshmanan, H. E. Brooks, and K. L. Ortega, 2012: An objective high-resolution hail climatology of the contiguous United States. Wea. Forecasting, 27, 1235-1248, CrossRef.

Darden, C. B., B. Carroll, S. Goodman, G. Jedlovec, and B. Lapenta, 2002: Bridging the gap between research and operations in the National Weather Service: Collaborative activities among the Huntsville meteorological community. NOAA Tech. Memo. NWS SR-222, NWS Southern Region, Fort Worth, TX, 29 pp. [Available online at www.srh.noaa.gov/ssd/techmemo/sr222.pdf.]

, D. J. Nadler, B. C. Carcione, R. J. Blakeslee, G. T. Stano, and D. E. Buechler, 2010: Utilizing total lightning information to diagnose convective trends. Bull. Amer. Meteor. Soc., 91, 167-175. CrossRef.

Davies-Jones, R., 1984: Streamwise vorticity: The origin of updraft rotation in supercell storms. J. Atmos. Sci., 41, 2991-3006, CrossRef.

, 2008: Can a descending rain curtain in a supercell instigate tornadogenesis barotropically? J. Atmos. Sci., 65, 2469-2497, CrossRef.

Deierling, W., and W. A. Petersen, 2008: Total lightning activity as an indicator of updraft characteristics. $J$. Geophys. Res., 113, D16210, CrossRef.

, J. Latham, S. Ellis, and H. J. Christian, 2008: The relationship between lightning activity and ice fluxes in thunderstorms. J. Geophys. Res., 113, D15210, CrossRef.

Demetriades, N. W. S., D. Buechler, C. Darden, G. R. Patrick, and A. Makela, 2008: VHF total lightning mapping data use for thunderstorm nowcasting at weather forecast offices. Preprints, Third Conf. on Meteorological Applications of Lightning Data, New Orleans, LA, Amer. Meteor. Soc., 8.5. [Available online at ams.confex.com/ams/pdfpapers/132095.pdf.]

Fawbush, E. J., and R. C. Miller, 1954: The types of airmasses in which North American tornadoes form. Bull. Amer. Meteor. Soc., 35, 154-165.

Fujita, T. T., 1975: New evidence from April 3-4, 1974 tornadoes. Preprints, Ninth Conference on Severe Local Storms, Norman, OK, Amer. Meteor. Soc., 248-255.

Gatlin, P. N., and S. J. Goodman, 2010: A total lightning trending algorithm to identify severe thunderstorms. $J$. Atmos. Oceanic Technol., 27, 3-22, CrossRef.

Goodman, S. J., D. E. Buechler, P. D. Wright, and W. D. Rust, 1988: Lightning and precipitation history of a microburst-producing storm. Geophys. Res. Lett., 15, 1185-1188, CrossRef.

, W. M. Lapenta, G. J. Jedlovec, J. C. Dodge, and J. T. Bradshaw, 2004: The NASA Short-term Prediction Research and Transition (SPoRT) Center: A collaborative model for accelerating research into operations. Preprints, 20th Int. Conf. on Interactive Information Processing Systems (IIPS) for Meteorology, Oceanography, and Hydrology, Seattle, WA, Amer. Meteor.
Soc., P1.34. [Available online at ams.confex.com/ams/ pdfpapers/70210.pdf.]

, and Coauthors, 2005: The North Alabama Lightning Mapping Array: Recent severe storm observations and future prospects. Atmos. Res., 76, 423-437, CrossRef.

, and _ 2012: The GOES-R Proving Ground: Accelerating user readiness for the next-generation geostationary environmental satellite system. Bull. Amer. Meteor. Soc., 93, 1029-1040, CrossRef. , and _ 2013: The GOES-R Geostationary Lightning Mapper (GLM). Atmos. Res., 126, 34-49, CrossRef.

Grzych, M. L., B. D. Lee, and C. A. Finley, 2007: Thermodynamic analysis of supercell rear-flank downdrafts from Project ANSWERS. Mon. Wea. Rev., 135, 240246, CrossRef.

Hodanish, S., D. Sharp, E. Williams, B. Boldi, A. Matlin, M. Weber, S. Goodman, and R. Raghavan, 1998: Observations of total lightning associated with severe convection during the wet season in central Florida. Preprints, 19th Conf. on Severe Local Storms, Minneapolis, MN, Amer. Meteor. Soc., 635-638.

, E. Williams, and B. Boldi, 2013: Early history of using total lightning data at NWS Melbourne, Florida. Electronic J. Severe Storms Meteor., 8 (6), 1-26. [Available online at www.ejssm.org/ojs/index.php/ ejssm/article/view/115/94.]

Jayaratne, E. R., C. P. R. Saunders, and J. Hallet, 1983: Laboratory studies of the charging of soft-hail during ice crystal interactions. Quart. J. Roy. Meteor. Soc., 109, 609-630, CrossRef.

Johnson, J. T., P. L. MacKeen, A. Witt, E. D. Mitchell, G. J. Stumpf, M. D. Eilts, and K. W. Thomas, 1998: The storm cell identification and tracking algorithm: An enhanced WSR-88D algorithm. Wea. Forecasting, 13, 263-276, CrossRef.

Kingfield, D. M., and M. A. Magsig, 2009. Leveraging National Weather Service technology for collaboration and training. Preprints, 25th Conf. on International Interactive Information and Processing Systems (IIPS) for Meteorology, Oceanography, and Hydrology, Phoenix, AZ, Amer. Meteor. Soc., P1.9. [Available online at ams.confex.com/ams/pdfpapers/150678.pdf.]

Kuhlman, K. M., C. L. Ziegler, E. R. Mansell, D. R. MacGorman, and J. M. Straka, 2006: Numerically simulated electrification and lightning of the 29 June 2000 STEPS supercell storm. Mon. Wea. Rev., 134, 2734-2757, CrossRef.

, D. Kingfield, G. Stano, E. Bruning, B. Baranowski, and C. Siewert, 2010: Use and evaluation of lightning data within the 2010 Experimental Warning Program and GOES-R Proving Ground. Preprints, 25th Conf. on Severe Local Storms, Denver, CO, Amer. Meteor. Soc., P4.2. [Available online at ams.confex.com/ams/ pdfpapers/176168.pdf.] 
Lang, T. J., and S. A. Rutledge, 2002: Relationships between convective storm kinematics, precipitation, and lightning. Mon. Wea. Rev., 130, 2492-2506, CrossRef.

Lee, B. D., C. A. Finley, and C. D. Karstens, 2012: The Bowdle, South Dakota, cyclic tornadic supercell of 22 May 2010: Surface analysis of rear-flank downdraft evolution and multiple internal surges. Mon. Wea. Rev., 140, 3419-3441, CrossRef.

Lemon, L. R., and C. A. Doswell III, 1979: Severe thunderstorm evolution and mesocyclone structure as related to tornadogenesis. Mon. Wea. Rev., 107, 11841197, CrossRef.

Lennon, C. L., 1975: LDAR - A new lightning detection and ranging system. Eos Trans. Amer. Geophys. Union, 56, 991.

, and L. Maier, 1991: Lightning mapping system. Preprints, International Aerospace and Ground Conference on Lightning and Static Electricity, Kennedy Space Center, FL, NASA CP-3106, Vol. 2, 89-1 to 8910.

Lhermitte, R., and P. R. Krehbiel, 1979: Doppler radar and radio observations of thunderstorms. IEEE Trans. on Geoscience Electron., 17, 162-171, CrossRef.

MacGorman, D. R., D. W. Burgess, V. Mazur, W. D. Rust, W. L. Taylor, and B. C. Johnson, 1989: Lightning rates relative to tornadic storm evolution on 22 May 1981. J. Atmos. Sci., 46, 221-251, CrossRef.

and Coauthors, 2008: TELEX: The thunderstorm electrification and lightning experiment. Bull. Amer. Meteor. Soc., 89, 997-1013, CrossRef.

Maggio, C., and Coauthors, 2005: Lightning-initiation locations as a remote sensing tool of large thunderstorm electric field vectors. J. Atmos. Oceanic Technol., 22, 1059-1068, CrossRef.

Maier, L. M., C. Lennon, T. Britt, and S. Schaefer, 1995: Lightning Detection and Ranging (LDAR) system performance analysis. Preprints, Sixth Conf. on Aviation Weather Systems, Dallas, TX, Amer. Meteor. Soc., 305-309.

Markowski, P. M., 2002: Hook echoes and rear-flank downdrafts: A review. Mon. Wea. Rev., 130, 852-876, CrossRef.

, and Y. P. Richardson, 2009: Tornadogenesis: Our current understanding, forecasting considerations, and questions to guide future research. Atmos. Res., 93, 310, CrossRef.

, E. N. Rasmussen, and J. M. Straka, 1998: The occurrence of tornadoes in supercells interacting with boundaries during VORTEX-95. Wea. Forecasting, 13, 852-859, CrossRef.

, J. M. Straka, and E. N. Rasmussen, 2003: Tornadogenesis resulting from the transport of circulation by a downdraft: Idealized numerical simulations. J. Atmos. Sci., 60, 795-823, CrossRef.
McCaul, E. W., Jr., J. C. Bailey, J. Hall, S. J. Goodman, R. J. Blakeslee, and D. E. Buechler, 2005: A flash clustering algorithm for North Alabama Lightning Mapping Array data. Preprints, Conf. on Meteorological Applications of Lightning Data, San Diego, CA, Amer. Meteor. Soc., 5.3. [Available online at ams.confex.com/ams/ Annual2005/techprogram/paper_84373.htm.] , S. J. Goodman, K. M. LaCasse, and D. J. Cecil, 2009: Forecasting lightning threat using cloud-resolving model simulations. Wea. Forecasting, 24, 709-729, CrossRef.

Metzger, E., and W. A. Nuss, 2013: The relationship between total cloud lightning behavior and radarderived thunderstorm structure. Wea. Forecasting, 28 , 237-253, CrossRef.

Nadler, D. J., C. B. Darden, G. T. Stano, and D. E. Buechler, 2009: An operational perspective of total lightning information. Preprints, Fourth Conf. on the Meteorological Applications of Lightning Data, Phoenix, AZ, Amer. Meteor. Soc., P1.11. [Available online at ams.confex.com/ams/pdfpapers/144210.pdf.]

Patrick, G. R., and N. W. S. Demetriades, 2005: Using LDAR II total lightning data in an operational setting: Experiences at WFO Fort Worth TX. Preprints, 21st Conf. on Weather Analysis and Forecasting, Washington, DC, Amer. Meteor. Soc., P6A.1. [Available online at ams.confex.com/ams/pdfpapers/94720.pdf.]

Proctor, D. E., 1971: A hyperbolic system for obtaining VHF radio pictures of lightning. J. Geophys. Res., 76, 1478-1489, CrossRef.

1981: VHF radio pictures of cloud flashes. $J$. Geophys. Res., 86, 4041-4071, CrossRef.

Rassmussen, E. N., S. Richardson, J. M. Straka, P. M. Markowski, and D. O. Blanchard, 2000: The association of significant tornadoes with a baroclinic boundary on 2 June 1995. Mon. Wea. Rev., 128, 174-191, CrossRef.

Rison, W., R. J. Thomas, P. R. Krehbiel, T. Hamlin, and J. Harlin, 1999: A GPS-based three-dimensional lightning mapping system: Initial observations in central New Mexico. Geophys. Res. Lett., 26, 3573-3576, CrossRef.

Roberts, R. D., and J. W. Wilson, 1995: The genesis of three nonsupercell tornadoes observed with dual-Doppler radar. Mon. Wea. Rev., 123, 3408-3436, CrossRef.

Schmit, T. J., M. M. Gunshor, W. P. Menzel, J. J. Gurka, J. $\mathrm{Li}$, and A. S. Bachmeier, 2005: Introducing the nextgeneration Advanced Baseline Imager on GOES-R. Bull. Amer. Meteor. Soc., 86, 1079-1096, CrossRef.

Schultz, C. J., W. A. Petersen, and L. D. Carey, 2009: Preliminary development and evaluation of lightning jump algorithms for the real-time detection of severe weather. J. Appl. Meteor. Climatol., 48, 2543-2563, CrossRef. , and 2011: Lightning and severe weather: A comparison between total and cloud-to-ground lightning trends. Wea. Forecasting, 26, 744-755, CrossRef. 
, L. D. Carey, E. V. Schultz, G. T. Stano, P. N. Gatlin, D. Kozlowski, R. J. Blakeslee, and S. J. Goodman, 2013: Integration of the total lightning jump algorithm into current operational warning environment conceptual models. Preprints, Ninth Symposium of Future Operational Environmental Satellite Systems, Austin, TX, Amer. Meteor. Soc., TJ30.4. [Available online at ams.confex.com/ams/93Annual/recordingredirect.cgi/id /24088.]

Smith, S. B., and Coauthors, 1998: The System for Convection Analysis and Nowcasting (SCAN). Preprints, 16th Conf. on Weather Analysis and Forecasting, Phoenix, AZ, Amer. Meteor. Soc., J22-J24.

Stano, G. T., 2012: Using total lightning observations to enhance lightning safety. Preprints, Seventh Symposium on Policy and Socio-Economic Research, New Orleans, LA, Amer. Meteor. Soc., 327. [Available online at ams.confex.com/ams/92Annual/webprogram/Manuscri pt/Paper202740/Stano_2012AMS 327.pdf.]

, H. E. Fuelberg, W. P. Roeder, 2010a: Developing empirical lightning cessation forecast guidance for the Cape Canaveral Air Force Station and Kennedy Space Center. J. Geophys. Res., 115, D09205, CrossRef.

, K. K. Fuell, and G. J. Jedlovec, 2010b: NASA SPoRT GOES-R Proving Ground Activities. Preprints, Sixth Symposium on Future National Operational Environmental Satellite Systems-NPOESS and GOES-R, Atlanta, GA, Amer. Meteor. Soc., 8.2. [Available online at ams.confex.com/ams/pdfpapers/163879.pdf.]

C. Darden, and D. Nadler, 2010c: Assessing operational total lightning visualization products - Preliminary results. Preprints, Third International Lightning Meteorology Conf., Orlando, FL, Vaisala, 14 pp.

, K. K. Fuell, and G. J. Jedlovec, 2011: Improved realtime lightning trend products. Preprints, Fifth Conf. on Meteorological Applications of Lightning Data, Seattle, WA, Amer. Meteor. Soc., 8.1. [Available online at ams.confex.com/ams/91Annual/webprogram/Manuscri pt/Paper182136/Improved_Real_Time_Lightning_Tren d Products.pdf.]

, B. Carcione, C. Siewart, and K. M. Kuhlman, 2012: Evaluation of NASA SPoRT's pseudo-Geostationary Lightning Mapper products in the 2011 Spring Program. Preprints, Eighth Symposium on Future Operational Environmental Satellite Systems, New Orleans, LA, Amer. Meteor. Soc., 501.

, J. A. Sparks, S. J. Weiss, and C. W. Siewert, 2013: Fusing total lightning data with Aviation Weather Center and Storm Prediction Center operations during the GOES-R Visiting Scientist Program. Preprints, Ninth Symposium on Future Operational Environmental Satellite Systems, Austin, TX, Amer. Meteor. Soc., 724. [Available online at ams.confex.com/ams/93Annual/ webprogram/Manuscript/Paper215183/stano_etal_VSP_tri p.pdf.]
Stumpf, G. J., A. Witt, E. D. Mitchell, P. L. Spencer, J. T. Johnson, M. D. Eilts, K. W. Thomas, and D. W. Burgess, 1998: The National Severe Storms Laboratory mesocyclone detection algorithm for the WSR-88D. Wea. Forecasting, 13, 304-326, CrossRef.

, B. C. Baranowski, D. M. Kingfield, K. M. Kuhlman, K. L. Manross, C. W. Siewert, T. M. Smith, and S. Stough, 2010: Real-time severe convective weather warning exercises at the 2010 Experimental Warning Program (EWP2010). Preprints, 25th Conf. on Severe Local Storms, Denver, CO, Amer. Meteor. Soc., 7B.2. [Available online at ams.confex.com/ams/pdfpapers/ 176208.pdf.]

Takahashi, T., 1978: Riming electrification as a charge generation mechanism in thunderstorms. J. Atmos. Sci., 35 , 1536-1548, CrossRef.

Tessendorf, S. A., L. J. Miller, K. C. Wiens, and S. A. Rutledge, 2005: The 29 June 2000 supercell observed during STEPS. Part I: Kinematics and microphysics. $J$. Atmos. Sci., 62, 4127-4150, CrossRef.

Thomas, R. J., P. R. Krehbiel, W. Rison, S. J. Hunyady, W. P. Winn, T. Hamlin, and J. Harlin, 2004: Accuracy of the Lightning Mapping Array. J. Geophys. Res., 109, D14207, CrossRef.

Thompson, R. L., R. Edwards, J. A. Hart, K. L. Elmore, and P. Markowski, 2003: Close proximity soundings within supercell environments obtained from the Rapid Update Cycle. Wea. Forecasting, 18, 1243-1261, CrossRef. , B. T. Smith, J. S. Grams, A. R. Dean, and C. Broyles, 2012: Convective modes for significant severe thunderstorms in the contiguous United States. Part II: Supercell and QLCS tornado environments. Wea. Forecasting, 27, 1136-1154, CrossRef.

Trapp, R. J., G. J. Stumpf, and K. L. Manross, 2005: A reassessment of the percentage of tornadic mesocyclones. Wea. Forecasting, 20, 680-687, CrossRef.

Tuell, J. P., S. S. Schotz, R. K. Henry, and D. Plummer, 2009: AWIPS technology infusion - Status update. Preprints, 25th Conf. on International Interactive Information and Processing Systems (IIPS) for Meteorology, Oceanography, and Hydrology, Phoenix, AZ, Amer. Meteor. Soc., 8A.1. [Available online at ams.confex.com/ams/pdfpapers/147164.pdf.]

Weber, M. E., E. R. Williams, M. M. Wolfson, and S. J. Goodman, 1998: An assessment of the operational utility of a GOES lightning map sensor. Project Report NOAA-18, MIT Lincoln Laboratory, Lexington, MA, $124 \mathrm{pp}$. [Available online at www.1l.mit.edu/mission/ aviation/publications/publication-files/noaa-reports/ Weber 2013 NOAA-18A WW-26698.pdf.]

White, K., B. Carcione, C. J. Schultz, G. T. Stano, and L. D. Carey, 2012: The use of the North Alabama Lightning Mapping Array in the real-time operational warning environment during the March 2, 2012, severe weather outbreak in Northern Alabama. Natl. Wea. Assoc. 
Newsletter, Oct. 2012, 2-3. [Available online at www.nwas.org/newsletters/pdf/news oct2012.pdf.]

Wiens, K. C., S. A. Rutledge, and S. A. Tessendorf, 2005: The 29 June 2000 supercell observed during STEPS.
Part II: Lightning and charge structure. J. Atmos. Sci., 62, 4151-4177, CrossRef.

Williams, E., and Coauthors, 1999: The behavior of total lightning activity in severe Florida thunderstorms. Atmos. Res., 51, 245-265, CrossRef. 